\title{
2. 病的老化とそのエストロゲンによる予防の機序
}

\author{
折茂 彰 ${ }^{1)}$ 井上 聡 ${ }^{1)}$ 野田 哲生 ${ }^{2)}$ 村松 正實 ${ }^{1)}$ \\ Key words : estrogen, estrogen receptor (ER), estrogen-responsive gene, efp (estrogen-responsive finger pro- \\ tein), senile disease
}

（日老医誌 $1999 ； 36 ： 95-98 ）$

\section{研究背景}

閉経後の女性における骨粗鬆症の増加は，高齢化が進 む現代社会において，高齢者が活動的な生活を送る上の 障害の 1 つとなっている. エストロゲン補充による骨粗 鬆症の改善に加えて, 最近では虚血性心疾患やアルツハ イマー型痴呆症などに対する治療効果も報告されてお $\eta^{1)}$ ，これら老年病に対するエストロゲンの有効性が期 待されている. 一方, 副作用として, 乳癌, 子宮内膜症 や子宮癌などの増加が大きな問題点となるが, プロゲス テロンとの併用にてこれらをある程度抑えることが可能 とされ, 今後エストロゲン, プロゲステロンの量比を検 討した臨床的研究が重要になってくると思われる.とは いえ, 最近の環境ホルモンの騷ぎの中, ホルモン補充療 法の適応を明確にすることおよびその安全性に関する理 解も染めていくことが必須である. そもそも女性に閉経 という現象がなぜ起こるのか，それは生体に対し有利な のか不利なのか, 加えてエストロゲンのこれら老年病に 対する効果, 及び発癌や細胞増殖に対する作用の分子機 構はほとんど明らかになっていないのである，我々はそ の第一歩として，エストロゲンの下流応答遺伝子の機能 解析を行うことによりエストロゲンの作用機構の解明を 検討している.エストロゲンをはじめとするステロイド， サイロイド，レチノイン酸などの脂溶性物質は, 細胞内 に拡散し核にある受容体に結合後，ホルモン応答配列に 結合して新たな下流応答遺伝子の転写活性化を引き起こ すことが知られている，我々はエストロゲン受容体との

The Molecular Mechanisms of Estrogen Action Against Senile Disease

1) Akira Orimo, Satoshi Inoue, Masami Muramatsu：埼 玉医科大学第二生化学

2) Tetsuo Noda：癌研細胞生物部

Akira Orimo

Email : aorimo@saitama-med.ac.jp

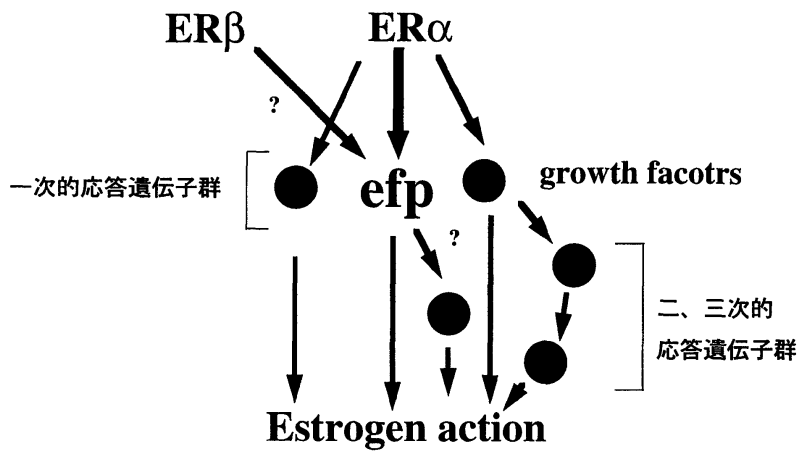

図1 エストロゲン作用の媒介因子としてのエストロ ゲン応答遺伝子群

結合性を利用して，3’の non-coding 領域にエストロゲ ン応答配列を有し RING finger motif を持ったエストロ ゲン下流応答遺伝子 efp を同定している2). RING finger motif は多くの転写調節因子に見つけれられており, 蛋 白一蛋白結合に重要であるとされ, その familyの多く のメンバーは癌化, 細胞増殖, アポトーシス, 細胞情報 伝達, 細胞周期, 発生など広範囲に関係し, 転写調節因 子として働くことがわかっている334). efp がエストロゲ ン情報伝達の媒介調節因子として働く可能性について, 今回作製した efp 遺伝子久損マウスの実験結果をもとに 考察したい.

\section{結果および考察}

efp は ER $\alpha$ の発現部位に一致して子宮の内膜細胞, 乳腺の上皮細胞や卵巣の顆粒膜細胞で強く発現してお り,また17ß-estradiol 刺激に対し子宮やヒト乳線由来細 胞などで約 2 〜 時間をピークとする迅速な応答性を示 したことから，一次的応答遺伝子としてある特定のエス トロゲン作用を媒介している可能性が示唆されてい $3^{25)}$. 図 1 に示すようにエストロゲン下流応答遺伝子群 は, エストロゲン受容体の直下で誘導される一次的応答 


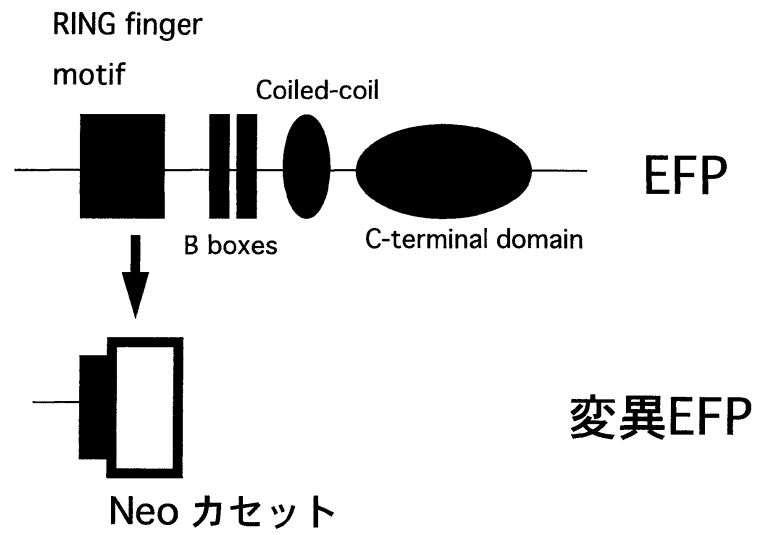

図 2 （1）ジーンターゲティング法によるマウス etp 遺 伝子の欠失 RING finger motif が削除され, Neo カセッ トが挿入された。

遺伝子群およびその後の二次的，三次的反応により誘導 されてくる二次的, 三次的応答遺伝子群に大別され，工 ストロゲンの多彩な作用に至るまでの媒介因子と考えら れる ${ }^{6}$. 一次的応答遺伝子群の中には，他に IGF (insulinlike growth factor）を代表とするいくつかの growth factorが知られている. また, 最近, 乳癌の原因遺伝子と して知られる BRCA1や cyclin D1などもエストロゲンで 誘導される（二次的, 三次的応答遺伝子群に属する）こ とが報告されておりり, エストロゲンと乳線上皮の増殖 や乳癌との関係および子宮内膜の増殖作用との関係で注 目されている，しかしながら，これらの遺伝子誘導がエ ストロゲン作用と直接関係するかについては不明であ る. 一方, 骨や血管においてもエストロゲン誘導性の遺 伝子は少数しか知られておらず，ヒト骨肉腫由来細胞株 にて, type1プロコラーゲンや TGF $\beta$ が9), ラット大腿 骨において TGF 33 発現が誘導されること ${ }^{10}$ が報告さ れている，また血管においては，エストロゲンが内皮型 nitric oxide synthase (NOS) の発現を誘導し, 血管拡 張作用を促す事が報告されている ${ }^{11)}$. 以前より我々は, 血管壁におけるエスロゲン受容体 $\alpha(\mathrm{ER} \alpha)$ の存在およ び受容体を介したエスロゲンの抗動脈硬化作用の可能性 を示唆してきており ${ }^{12 \sim 14)}$ ，また efp 遺伝子が血管平滑筋 細胞や骨芽細胞で発現していることょり, efp ホモ接合 体マウスの脈管系や骨格系について解析を行うことを計 画した. efp 遺伝子久損マウスは RING finger domain の一部を PGK-neo カセットで置き換えた形の targeting vector に起因し（図 2-1）その後 efp 変異 ES（Embryonic Stem）cell を選択し blastocyst に microinjection す ることによりキメラマウスを得て，ヘテロ接合体マウス 同士の掛け合わせによりホモ接合体マウスが得られた. 発生に必須の因子 ${ }^{15}$ である場合は, 胎生致死になる事が

\begin{tabular}{|c|c|c|}
\hline \multicolumn{2}{|c|}{ ヒトER $\alpha$ 遺伝子異常症 } & $\mathrm{ER} \alpha$ 遺伝子久損マウス \\
\hline 身体所見 & $\begin{array}{l}\text { 高身長 }(204 \mathrm{~cm}) \\
\text { 外反肘, 黒色棘細胞 } \\
\text { 症 }\end{array}$ & 正常範囲 \\
\hline 骨格系 & $\begin{array}{l}\text { 骨端線末閉鎖 } \\
\text { 骨量減少 ( - 2SD) }\end{array}$ & $\begin{array}{l}\text { 骨量異常 } \\
\text { (雄では骨量低下, 雌では上 } \\
\text { 昇傾向) }\end{array}$ \\
\hline 血管系 & 冠働脈の石炭化 & $\begin{array}{l}\text { 機械的血管内膜障害に対す } \\
\text { るエストロゲンの血管保護 } \\
\text { 作用の残存 }\end{array}$ \\
\hline 精子所見 & $\begin{array}{l}\text { 精子数正常 } \\
\text { 精子生存率低下 }\end{array}$ & $\begin{array}{l}\text { 精子形成障害，精巣萎縮 } \\
\text { 不弤娠 }\end{array}$ \\
\hline 女性生殖器 & & $\begin{array}{l}\text { 子宮, 乳腺：低形成 } \\
\text { 卵宩: 過形成, 排卵障害に } \\
\text { よる不妊症 }\end{array}$ \\
\hline
\end{tabular}

図 3 ヒト $\mathrm{ER} \alpha$ 遺伝子異常症と $\mathrm{ER} \alpha$ 遺伝子久損マウスの比較

多いが efp ホモ接合体マウスは, Southern blotによる genotypeの結果よりメンデルの法則に従って生まれて くることがわかった. また, Northern blot解析や Western blot 解析にてホモ接合体マウスでは完全な efp 蛋白 の欠損が確認された。 efp ホモ接合体マウスの動脈硬化 症に関する解析として, コレステロール $\operatorname{diet}$ 投与後の 血管壁の性状および血管内皮障害やカフモデルなどに関 しても現在検討中である．また，骨格系に関しては現在 骨密度等を定量中であり, 老化性の変化も含めて鋭意追 究する予定である。

図 3 に示す様に1994年に $\mathrm{ER} \alpha$ 遺伝子の変異をホモ接 合体で持った男性例 ${ }^{16 ~ 18)}$ が報告され，また1993年にエス トロゲン受容体 $\alpha(\mathrm{ER} \alpha)$ の遺伝子欠損マウス ${ }^{19-25)}$ が作 製されて以来, エストロゲン研究は急速な進歩を遂げて いるが, ここで問題となるのはこれらのモデルにおいて $\mathrm{ER} \alpha$ 遺伝子の機能欠損が, 必ずしも骨量の減少や動脈 硬化を引き起こさなかったことである.つまり $\mathrm{ER} \alpha$ 遺 伝子変異を有した症例には確かに骨量の減少がみられた が, その家系自体に骨量減少傾向がみられ遺伝子特異的 な変化とは言い切れないこと, また明らかな虚血性心疾 患の既往が認められていないこと ${ }^{17)}$. 加えて, $\mathrm{ER} \alpha$ 遺伝 子欠損マウスに打いても，雄では骨量減少が見られたも のの, 雌では逆に増加傾向にあったことや, 機械的血管 内皮障害に対する血管保護作用が残存していた ことが 報告されたのである.これらの現象の解釈として, 1996 年に新規のエストロゲン受容体として発見された ER ${ }^{26 \sim 28)}$ (核内受容体の familyに属し $\mathrm{ER} \alpha$ に非常によ く類似した構造を持つ）の代償作用を考えることができ る. ERßは,リガンド結合実験や転写活性化実験など より, $\mathrm{ER} \alpha$ 同様にエストロゲンの受容体として機能す ることが証明されており, 加えて $\mathrm{ER} \alpha$ との結合実験に 


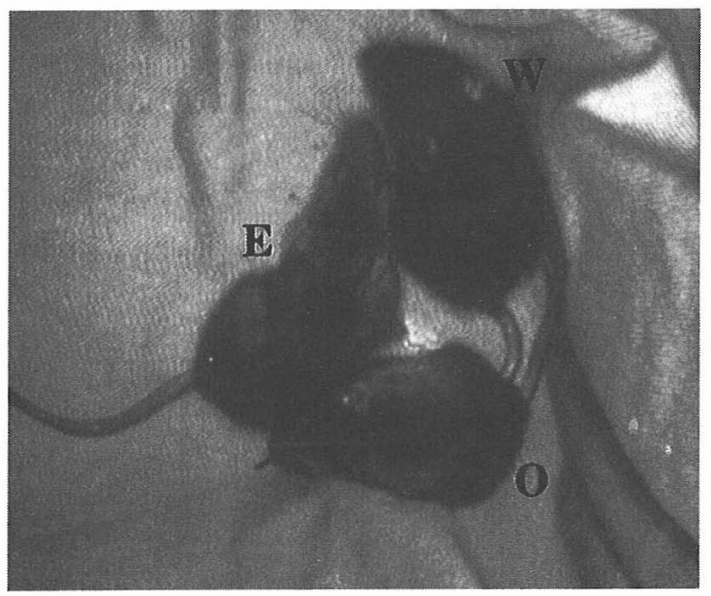

図 2 （2）efp 遺伝子欠損マウスの外見 $\mathrm{W}$ ：野生型, $\mathrm{E}$ ：ヘテロ接合体マウス, $\mathrm{O}$ ：ホモ接合体 マウス

よりへテロダイマー，ホモダイマーを形成することも示 されている29.30). 成体内機能に関してはまだはっきりし ていないが，今後は $\mathrm{ER} \alpha, \mathrm{ER} \beta$ 欠損モデルの解析が待 たれるところであり，それらの下流応答遺伝子の解析に ついても次の step として行われるべき課題である.

最後に, efp ホモ接合体マウスで現在わかっている異 常についてふれると, efp ホモ接合体マウスは成長障害 などを来す事なく発育するが（図 $2-2$ ), 性周期の一致 した各群の雌マウスの子宮重量/全体重を比較したとこ ろホモ接合体マウスにおいて有意に子宮重量/全体重の 減少が確認された。 また, 卵巣摘出手術後 2 週間後の各 群の雌マウスにエストロゲンを投与し，その反応性を子 宮重量/全体重の増加の割合で比較したところ，ホモ接 合体マウスにおいて子宮重量/全体重の増加は有意に低 值であった（折茂 彰ら投稿準備中）。この様なホモ接 合体マウスにみられた子宮における低形成およびエスト ロゲン低応答性は, efp が子宮内膜の増殖をエストロゲ ン依存性に positiveに制御している可能性を示唆してお り，増殖因子，細胞周期関連蛋白などとの関係について のメカニズムの検討が興味深いところである、また，こ れらの異常の程度は $\mathrm{ER} \alpha$ 遺伝子欠損マウスの異常と比 較すると軽度であり，他の下流応答遺伝子による代償機 構が働いている事が十分に予測され，生体のネットワー クの多様性を想像させられる. 今後も複数の応答遺伝子 の単離そしてその遺伝子久損マウスの作製に加え，遺伝 的な掛け合わせ実験等により，エストロゲンの受容体以 降の情報伝達を明らかにしていきたい. 加えて閉経や動 脈硬化症や骨粗䉘症といった老年病との関係を追求して いきたい。
おわりに

本稿では，病的老化である骨粗馨症や動脈硬化症に対 するエストロゲン予防効果のメカニズムについて下流応 答遺伝子を中心に記載した. 下流応答遺伝子に関する研 究は核内受容体以外の他の転写因子でも同様に，今後更 に追求していかなければならない未知の分野の一つであ る. 今後, 病的老化以外に正常老化現象に対寸る性ホル モンの作用メカニズムに関しても追求したい.

\section{文献}

1) Tang MX, Jacobs $D$, Stern $Y$, Marder $K$, Schofield $P$, Gurland $\mathrm{B}$, et al. : Effect of oestrogen during menopause on risk and age at onset of Alzheimer's disease. Lancet $1996 ; 348: 429-432$.

2) Inoue $\mathrm{S}$, Orimo $\mathrm{A}$, Hosoi $\mathrm{T}$, Kondo $\mathrm{S}$, Toyoshima $\mathrm{H}$, Kondo $\mathrm{T}$, et al.: Genomic binding-site cloning reveals a novel estrogen responsive gene that encodes a RING finger protein. Proc Natl Acad Sci USA 1993; 90 : 1111711121.

3) Saurin AJ, Borden KLB, Boddy MN, Freemont PS : Does this have a familiar RING? TIBS $1996 ; 21: 208-214$.

4) Orimo $A$, Inoue $S$, Ikeda $K$. Sato M, Kato $A$, Tominaga $N$, et al. : Molecular cloning, localization and developmental expression of mouse brain finger protein (ZNF179) ; distribution of bfp mRNA partially coincides with the affected areas of Smith-Magenis Syndrome (SMS). Genomics, $1998 ; 54,59-69$.

5) Orimo A. Inoue S, Ikeda K, Noji S. Muramatsu M: Molecular cloning, structure and expression of mouse estrogen-responsive finger protein (efp) ; co-localization with estrogen receptor mRNA in target organs. J Biol Chem $1995 ; 270: 24406-24413$.

6）折茂 彰,井上 聡, 村松正実：エストロゲンレセプター の下流応答遗伝子とその生体内機能. 実験医学 1998; $16: 2447-2453$.

7) Marks JR, Huper G, Vaughn JP, Davis PL, Norris J, McDonnell DP, et al. : BRCA1 expression is not directly responsive to estrogen. Oncogene $1997 ; 14: 115-121$.

8) Altucci L, Addeo R, Cicatiello L, Dauvois S, Parker MG, Truss $\mathrm{M}$, et al. : 17beta-Estradiol induces cyclin D1 gene transcription, p36D1-p34cdk4 complex activation and $\mathrm{p}$ $105 \mathrm{Rb}$ phosphorylation during mitogenic stimulation of G (1)-arrested human breast cancer cells. Oncogene $1996 ; 12: 2315-2324$.

9) Komm BS, Terpening CM, Benz DJ, Graeme KA, Gallegos A, Korc M, et al. : Estrogen binding, receptor mRNA, and biologic response in osteoblast-like osteosarcoma cells. Science $1988 ; 241: 81-84$.

10) Yang NN, Bryant HU, Hardikar S, Sato M, Galvin RJ, 
Glasebrook AL, et al. : Estrogen and raloxifene stimulate transforming growth factor-beta 3 gene expression in rat bone: a potential mechanism for estrogen-or raloxifene-mediated bone maintenance. Endocrinology 1996; 137 : 2075-84.

11) Binko J, Majewski $H: 17$ beta-Estradiol reduces vasoconstriction in endothelium-denuded rat aortas through inducible NOS. Am J Physiol 1998; $274: 853$-859.

12) Orimo A, Inoue $S$, Ikegami $A$, Hosoi $T$, Akishita M, Ouchi $Y$, et al. : Vascular smooth muscle cells as target for estrogen. Biochem Biophys Res Commun 1993; 195 : 730736.

13) Orimo A, Inoue $\mathrm{S}$, Ouchi, $\mathrm{Y}$, Orimo, $\mathrm{H}$ : Vascular smooth muscle cells possess estrogen receptor and respond to estrogen. Ann NY Acad Sci 1995 ; $748: 592$ - 594.

14) Akisita M, Ouchi $Y$, Miyoshi H, Orimo A, Kozaki K, Eto $M$, et al. : Estrogen inhibits endothelin-1 production and c-fos gene expression in rat aorta. Atherosclerosis 1996; $125: 27-38$.

15) Okuda A, Fukushima A, Nishimoto M, Orimo A, Yamagishi T, Nabeshima Y, et al. :UTF1, a novel transcriptional coactivator expressed in pluripotent embryonic stem cells and extra-embryonic cells. EMBO J 1998; 17 : 2019-2032.

16) Smith EP, Boyd J, Frank GR, Takahashi H, Cohen RM, Specker B, et al. : Estrogen resistance caused by a mutation in the estrogen-receptor gene in a man. $\mathrm{N}$ Engl $\mathrm{J}$ Med $1994 ; 331: 1056-1061$.

17) Sudhir K, Chou TM, Chatterjee K, Smith EP, Williams TC, Kane JP, et al. : Premature coronary artery disease associated with a disruptive mutation in the estrogen receptor gene in a man. Circulation $1997 ; 96: 3774-3777$.

18) Sudhir K, Chou TM, Messina LM, Hutchison SJ, Korach $\mathrm{KS}$, Chatterjee $\mathrm{K}$, et al.: Endothelial dysfunction in a man with disruptive mutation in oestrogen-receptor gene. Lancet $1997 ; 349: 1146-1147$.

19) Lubahn DB, Moyer JS, Golding TS, Couse JF, Korach KS, Smithies O : Alteration of reproductive function but not prenatal sexual development after insertional disruption of the mouse estrogen receptor gene. Proc Natl Acad Sci USA $1993 ; 90: 11162-11166$.

20) Korach KS:Insights from the study of animals lacking functional estrogen receptor. Science $1994 ; 266$ : 1524-
1527.

21) Couse JF, Curtis SW, Washburn TF, Lindzey J, Golding TS, Lubahn DB, et al. : Analysis of transcription and estrogen insensitivity in the female mouse after targeted disruption of the estrogen receptor gene. Mol Endocrinol $1995 ; 9: 1441-1454$.

22) Eddy EM, Washburn TF, Bunch DO, Goulding EH, Gladen BC, Lubahn DB, et al.: Targeted disruption of the estrogen receptor gene in male mice causes alteration of spermatogenesis and infertility. Endocrinology $1996 ; 137: 4796$ - 4805 .

23) Hess RA, Bunick D, Lee KH, Bahr J, Taylor JA, Korach $\mathrm{KS}$, et al. : A role for oestrogens in the male reproductive system. Nature $1997 ; 390: 509-512$.

24) Iafrati MD, Karas RH, Aronovitz M, Kim S, Sullivan TR Jr, Lubahn DB, et al. : Estrogen inhibits the vascular injury response in estrogen receptor alpha-deficient mice. Nat Med 1997 ; $3: 545-548$.

25) Rubanyi GM, Freay AD, Kauser K, Sukovich D, Burton G, Lubahn DB, et al.: Vascular estrogen receptors and endothelium-derived nitric oxide production in the mouse aorta. Gender difference and effect of estrogen receptor gene disruption. J Clin Invest 1997 ; $99: 2429$ - 37 .

26) Kuiper GG, Enmark E, Pelto-Huikko M, Nilsson S, Gustafsson JA : Cloning of a novel receptor expressed in rat prostate and ovary. Proc Natl Acad Sci USA 1996; 93 : $5925-5930$.

27) Ogawa $\mathrm{S}$, Inoue $\mathrm{S}$, Watanabe $\mathrm{T}$, Hiroi H, Orimo A, Hosoi $\mathrm{T}$, et al. : The complete primary structure of human estrogen receptor $\mathrm{b}(\mathrm{ERb})$ and its heterodimerization with ERa in vivo and in vitro. Biochem Biophys Res Commun $1998 ; 243: 122-126$.

28) Lindner V, Kim SK, Karas RH, Kuiper GG, Gustafsson JA, Mendelsohn ME:Increased expression of estrogen receptor-beta mRNA in male blood vessels after vascular injury. Circ Res $1998 ; 83: 224-229$.

29) Pettersson K, Grandien K, Kuiper GG, Gustafsson JA : Mouse estrogen receptor beta forms estrogen response element-binding heterodimers with estrogen receptor alpha. Mol Endocrinol $1997 ; 11: 1486$ - 1496 .

30) Cowley SM, Hoare S, Mosselman S, Parker MG : Estrogen receptors alpha and beta form heterodimers on DNA. J Biol Chem 1997 ; 272 : 19858-19862. 